\title{
Promoting women and minorities owned enterprises in African countries.
}

\author{
N C Ozigbo ${ }^{1}$ and P Ezeaku ${ }^{2}$
}

\begin{abstract}
This paper attempts to examine the key issues relating to African women and minority owned enterprises development in the context of its relationship with economic development. The analysis is further broadened to underscore the determinants of women entrepreneurship development and the environment conducive for its operations. In addition, the policies that are necessary to make this environment favorable are discussed. The generic constraints faced are also listed out. The paper shows the need to accelerate economic development in African countries through promotion of women and majorities owned enterprises. Entrepreneurial orientations should be based on stimulating local entrepreneurial talent and subsequent growth of indigenous companies. This in turn would create jobs and add economic value to the region and at the same time keep scarce resources within the region. The paper recommends that African women and minority owned enterprises should be encouraged and taught to develop new entrepreneurial life styles, capacities, develop global sensitivity and strategic thinking capabilities. Therefore, greater gender equality, better institutions and more efficient economic functioning could possibly lead to access to opportunities, rights and voice.
\end{abstract}

\section{Introduction}

Entrepreneur, translated from its French roots, means "one who undertakes." The term is used to refer to anyone who undertakes the organization and management of an enterprise involving independence and risk as well as the opportunity for profit ${ }^{3}$. Similarly, others also define an entrepreneur as a person who has the ability to scan and identify opportunities in his/her environment, gather the resources necessary to take advantage of the opportunities and implement successful action to utilize the

\footnotetext{
${ }^{1}$ Department of Business Administration, University of Abuja, Nigeria (E-mail: stanozconsult@yahoo.com_ ).

${ }^{2}$ Urban Management Program; Ethiopian Civil Service College, P. O. Box 5648, Addis Ababa, Ethiopia (E-mail: ezeakup@yahoo.com, corresponding author).

${ }^{3}$ Available at http://www.searchcio.techtarget.com.
} 
opportunities (Baumol, 1990; Gibb, 1998). They are traditionally risk takers who identify opportunities, undertake calculated risks and mobilize resources. Entrepreneurs are recognized as the prime movers of economic development (Petrin, 1994), the people who translate ideas into action.

Scholars who have studied entrepreneurial behaviors have identified certain traits for successful operations of the enterprise, such as innovativeness, ability and willingness to take calculated risks, determination, total involvement, insight, independence, need for achievement and leadership (Gibb, 1998; Hisrick et al 1999). In recognition of these, most African governments have implemented wide-ranging strategies to encourage women and minorities to initiate their own small businesses. The focus for this effort is small scale enterprise development.

It is understood that African societies have had indigenous entrepreneurs but contemporary African entrepreneurship has failed to be a catalyst for socioeconomic development (Starcher, 2003). While most regions of the world witness increased living standards and greater economic opportunity, Africans continue to face famine, poverty and political corruption. One of the contributing factors to this situation may be inadequate application of the human factors (HF) ingredients such as integrity, communal spirit, responsibility, accountability, self-reliance and cooperation as well as those earlier mentioned by Gibb (1998) and Hisrick et al (1999).

These HF, according to UNDP (1995), constitute the underlying matrix that ties entrepreneurship and socioeconomic development together, an indication that entrepreneurs with these business traits are catalysts for socioeconomic development. Against this backdrop, the paper suggests the inculcation of the human factor in contemporary African entrepreneurs through education and training programs. Entrepreneurship development in Africa is very important given the significant role it played as a contributor to the industrial revolution in England in the mid-eighteen century (Carrce, 1997). Similarly, entrepreneurship has been central in the socio-economic development of other western European countries.

This paper emphasizes that promoting women's entrepreneurship could be a channel for instituting mechanisms that might provide 
greater protections, security and safety to women and minorities entrepreneurs and their families and communities. It will further ensure that women, particularly marginalized women and minorities become aware of their rights and entitlements to available resources. This might contribute to African women and minorities involvement in entrepreneurship and thus combat discrimination in the labor market.

\section{Statement of the problem}

In Africa, the equal rights of women and minorities and their equal participation in the social, cultural, economic and political life have remained illusive. As such, they are still the main victims of poverty, social prejudice, lack of access to health services and education. African women and minorities entrepreneurship development is generally inadequate and beset with numerous constraints and challenges, which have to do with culture, religion and entrepreneurial behaviors such as lack of innovativeness, ability and willingness to take calculated risks, determination, total involvement, insight, and lack of economic independence and their role perceptions in entrepreneurship.

There is dearth of current studies on how entrepreneurship in developing nations, or the lack of it, contributes to global inequality. In other words, entrepreneurial studies have not significantly contributed to the understanding of African women and minorities involvement in wealth creation and poverty alleviation. This necessitates the need to re-emphasize through entrepreneurship research the participation of women and minorities in Africa socio-economic development.

The researchers recognize that the process of starting a business is highly interactive and that it is a combination of personality as well as environmental factors that motivate individuals. Hence, the lead for this study was taken from recent holistic studies on women and minorities entrepreneurs. The aim is not to provide generalization concerning women and minorities entrepreneurs but to provide an initial basis for deepening our conceptual understanding on women entrepreneurs in Africa. A more dynamic understanding of entrepreneurship gives richer insights into its relevance to capitalist enterprise today. 


\section{Objectives}

The general objective of this paper is to identify the reasons for promoting women and minorities entrepreneurship as forces of socio-economic development in Africa. The specific objectives are to i) identify the problems, generic constraints and needs of women and minorities entrepreneurs; ii) Validate them in objective perspectives; iii) Based on the information gathered draw conclusions and make some policy and strategic recommendations that are conducive for entrepreneurship growth in African countries.

\section{Approach and methodology}

Contextually, methodology of the study revolves around women and minorities enterprise promotion in African countries. An understanding of the causes and constraints of women and minorities enterprise development is important. The qualitative and analytical research approach was used for the study because it aimed at evaluating the strategic importance of women and minorities entrepreneurial development. Secondary data was extensively sourced and used in the discussion within the spatial boundary of some African countries such as Cote d'Ivoire, Nigeria, Ethiopia, Senegal and Zimbabwe. Indicative examples of the data collected were presented in tables.

In spite of the widely recognized fact that it is one of the important sectors of the economy with great potential to contribute to economic growth and employment generation, the data available only skims the surface.

The following factors that affect women entrepreneurs in selected African countries are used in the analysis. They include:

- Gender and geographic location

- Poverty

- Vulnerability

- Family responsibilities

The study also evaluates other factors such as access to capital, labor issues, inadequate education and training as well as 
discrimination as constraints affecting the establishment as well as the expansion of women entrepreneurial activities.

\section{The global context of women entrepreneurs}

Women entrepreneurs in developed countries enjoy many advantages over those in developing countries in that they have access to greater support from women mentors and role models and easier access to formal training in the principles of business planning and organization (Hisrick and Ozturk, 1999). Similarly, Tyson and Petrin (1994) emphasize that women in developed countries have access to capital and the acceptance of women as business owners has improved, whereas women in developing countries do face obstacles such as lack of access to education and finance. In the developed countries, women entrepreneurs have become a driving force in today's modern economy. They shape and redefine the workplace, business networks, financial institutions and culture. A number of program initiatives such as education and training are also designed to motivate women entrepreneurs.

Studies have shown that the experience of women in business is different from those of men and that there is profound gender differences in both women experiences of business ownership and the performance of women owned enterprises (Starcher, 2003; Petrin, 1994). Most of the studies on women entrepreneurs limited largely to women in developed countries and have attempted to concentrate on unique aspects of the entrepreneurship of women. Their studies investigated the demographic characteristics of women, their motivations and reasons for start-up.

Recent study indicates that women face different issues depending on the stage of their personal life cycle and role perception in business (Skapa, 2005). Understanding the different goals that women have for entrepreneurship in the global context and the relationship between these goals and the structural factors that influence women's entrepreneurship would be of great help to researchers, planners as well as practitioners working to promote women entrepreneurs in developing countries, especially on the African continent. This understanding could lead to the 
development of an African paradigm, more fine-tuned policies and programs of support for women entrepreneurs.

On the African context, there are very few studies on women entrepreneurs. This is largely due to the lack of indigenous research studies, lack of information, due to limitation in contextual African methodologies, lack of relevant and up-to date and inappropriate instruments (Gelb, 2001). African women entrepreneurs follow a path that is in most cases different from entrepreneurial activities in the developed countries. In Africa, entrepreneurial activities are gendered in terms of access, control and remuneration (UNIDO, 2004; World Bank, 2005). In many African countries, women still do not have equal economic rights and access to resources as men. Under these conditions, women are unable to take full advantage of the economic opportunities presented by transition. Women in Africa tend to work in small scale enterprises, informal sector activities seems to be the norm on the continent. Engendered access to control and remuneration creates handicaps that include insufficient capital, limited expansion and women's networks being restricted to micro-entrepreneurial activities.

Also, OECD (1997) report shows that factors such as the collapse of the banking system, poor transportation systems, unavailability of foreign exchange, harassment, extortion, and arrest of entrepreneurs for illegal activities undermine African women and minorities entrepreneurial development. Stotsky (2006) identifies lack of capital, landlessness, discrimination and lack of adequate training as constraints for expansion of entrepreneurial activities.

The foregoing suggests that the key challenges facing women entrepreneurs in Africa are as follows:

- Inadequate access to formal credit,

- Vulnerability of women to adverse effects of trade reform,

- Restraints with regard to asset,

- Lack of information to exploit opportunities,

- Poor mobilization of women entrepreneurs.

For sustainable development to succeed in Africa, the participation of women in the economy needs to be promoted by reducing poverty amongst females, increasing their access to education 
opportunities and enhancing their access to power and decisionmaking (UNDP, 2005).

As women are an emerging sector in the global business environment, support is a potentially important means of raising the level of entrepreneurship in society. Support for women in business should encompass the following interventions:

- Encouraging and assisting them in relevant business support initiatives.

- Providing appropriate financial assistance to women entrepreneurs.

- Providing general information and education programs.

- Monitoring and support for networking structures.

The probability of a woman becoming an entrepreneur could be increased by exposure of the individual to formal learning experiences and to the tasks associated with owning a business. This exposure could be accomplished through mentors or role models in the workplace, home career guidance, internships and cooperative education programs (UNIDO, 2005; World Bank, 2005). Given the increasingly international nature of the business environment, there is the need for introducing specific measures to enable women entrepreneurs in developed countries to communicate and support their counterparts in developing countries (OECD, 1998). Three types of support are possible:

- Operational support: represents the amount of support provided in the way of advice and/or expertise.

- Emotional support: considers the encouragement provided to the women by others.

- Financial support.

Because of limited opportunities in the formal sector in Africa, many women are forced to work in the poorly paid and largely unregulated informal sector. Access and control over resources are still based on gender and class. In other words, male dominance over women in resource access and control is still in vogue in Africa. This phenomenon of gender inequality to access and use of resources has placed many African woman in low economic status (poverty) and social disintegration, including unemployment. 


\section{The entrepreneurship concepts}

The next two sections will dwell on the basic notation of the global context of women entrepreneurs and the challenges facing the African women entrepreneurs. This section of the paper deals with the different theories that have been put forward regarding the role of entrepreneur in economic development. These ranges from debates about the role of social change in capitalism to the more recent theory of the development state which emphasizes the entrepreneurial role of the state and perhaps most famous the Schumpeterian theory.

Major historical study of entrepreneurship started in the 1940s. Schumpeter (1947) examined the very nature of entrepreneurship and the great extent to which its character differed from place to place and over the course of time. Schumpeter (1975) notes the theory of entrepreneurship as the dynamic engine at the heart of capitalism. He portrayed entrepreneurs as the critical agents for economic change and development, while Say (1855) in his earlier theoretical development of entrepreneurship noted that the supply of entrepreneurship was critical in determining the wealth and growth of a nation's economy.

Early social scientific investigations of entrepreneurship focused not only on entrepreneurs and their firms but also with the structure of and changes in the industries, markets, societies, economies, and political systems in which they operate (Jenks, 1944, 1949; Schumpeter, 1949; Landers, 1958; Morris, 1967; Yamamura, 1968; Galambo, 1970; Sass, 1978). Jenks (1944) initiated empirical studies on the rise of entrepreneurship in the transition to capitalism and inspired a wave of comparative historical investigations that examined the emergence and social conditioning of entrepreneurship in countries around the world. Haggen (1962) emphasized the importance of innovation and technological creativity in England, Japan, Columbia, and Burma. Wilken's comparative study of entrepreneurship delved into the histories of Great Britain, France, Germany, USA, and Russia. Kilby (1971) and Leff (1979) gave historical record of entrepreneurship in the developing regions of Africa, Latin America, and Asia. 
The stream of research since the early studies have resulted in a large body of literature that amounted to the cumulative case that the levels and character of entrepreneurship varied significantly over time and space and is essentially determined by historical and social contexts. For instance, Wilken (1979) noted the theories that considered the role of social norms and legitimacy as well as social mobility in understanding the supply of entrepreneurship in a society. Low and MacMillan (1988) as well as Shane and Venkataraman (2000) have observed that entrepreneurial phenomena needed to be studied simultaneously at the micro (individual, firm) and macro (industry, region, economy) levels because of i) the interactions between the two, and ii) they are crucial engine driving the change process in "a capitalist society."

Modern theory emphasized social changes, including the unleashing of entrepreneurial creativity, as forming the basis of sustained economic growth among wealthy western countries and similar changes would inevitably spark the 'take off' of developing economies (Weiner, 1966). In this circumstance, according to Weiner, history assumed the role of an instrumental tool in the social scientific search for the causes of a supposedly unique set of entrepreneurial traits and 'personality.' The need to understand the determinants of entrepreneurship is as important as understanding its concept. The origins and determinants of entrepreneurship span a wide spectrum from theories and explanations (Brock and Evans, 1989).

Wallterstein (1974) criticized the modern theory of institutional mechanism for disregarding the diversity of options that developing nations encountered, as well as the historical interactions between national economies that had created structural inequalities in power and wealth between nations. In other wards, attention is placed on economic and institutional circumstances that face nations, while complex non-economic determinants of entrepreneurship such as social, religions and cultural determinants are ignored.

Social factors play significant role in the decision to become an entrepreneur, because as shown by a growing literature, social interactions affect the payoffs from a variety of economic decisions (Giannetti and Simonov, 2003; Casson, 995). A widely accepted view is the personal characteristics or traits as well as social 
aspects. Entrepreneurship could be developed through conscious action. Research analyzing the determinants of the decision to start a new business has so far stressed the role of individual characteristics, access to capital and institutions (Casson, 2003).

Development of entrepreneurs and entrepreneurship could be stimulated through a set of supporting institutions and through deliberate innovative action which stimulates changes and fully supports capable individuals or groups (Petrin, 1994). Therefore, policies and programs designed specifically for entrepreneurship promotion could greatly affect the supply of entrepreneurs and thus indirectly represent an important source of entrepreneurship. This view has important implications for entrepreneurship development.

The implications are explicit in William Baumol's well-known essay of 1990 on productive, unproductive, and destructive entrepreneurship, which provides an excellent illustration on theories of the supply of entrepreneurship. He argues that, in fact, the allocation of entrepreneurship between productive and unproductive ends varies much more widely than the total supply of entrepreneurial skill and hence is more important to long-term innovation and productivity growth of a society. He believed that the entrepreneurial activities are unquestionably considered engines of economic growth and innovation. As such, they are among the ultimate determinants of the large regional differences in economic performance.

Petrin (1994) and Gibb (1998) have stressed that in order to understand the role played by an entrepreneur in developing an economy, that it is first important to understand the concept of entrepreneurship. There are several definitions of entrepreneurships, but the most appropriate definition is a combination of three:

A force that mobilizes other resources to meet unmet market demand; the ability to create and build something from practically nothing, and the process of creating value by pulling together a unique package of resources to exploit an opportunity (Stevenson, 1985).

A "born-global" entrepreneurial firm is usually defined in the entrepreneurship and international business literatures as a start-up 
company that "from inception seeks to derive significant competitive advantage from the use of resources and the sale of outputs in multiple countries (Oviatt and McDougall, 1994). Stevenson (1985) noted that it is important not only to choose definition for entrepreneurship that is most appropriate, but also to bear in mind the skills and methods that would be needed to improve the quality of life for individuals and to sustain a healthy economy and environment.

The new business approach by entrepreneurs is to introduce new goods and services into the market, develop new methods of production, and open up new markets and pioneer new forms of business organization. In realization of these, according to Schumpeter (1975), entrepreneurs are expected to play a crucial role in adapting technologies to local needs and promoting structural changes which alter the national position in the international division of labor. The emphasis on the importance of entrepreneurship does not necessarily under-play the potential role of state intervention. Policies can influence the supply of entrepreneurs in the economy and the allocation of their resources and public interventions could influence accessibility to resources, technology and product markets.

\section{Challenges facing African women in industrial development}

Regional typology studies on the role of women done by UNIDO $(1995,2005)$ revealed empirical evidence that women have been in paid employment and in particular, their participation in industrial development improves their quality of life, literacy and life expectancy, while decreasing their fertility rate. Remunerative employment opportunities also enable women to fight poverty. The studies by UNIDO (ibid) further emphasize that women's productive activities empower them economically and enable them to contribute more to overall development. In many African societies, women do not enjoy the same opportunities as men. At the same time, in some African countries, progress has been achieved in opening doors to education and health protection, while in others; political and economic opportunities for women have remained limited. 
Generally, concerted efforts are needed to enable women to make better economic choice and to transfer their businesses into competitive employment through improved production.

Gelb (2001) emphasizes that small and medium sized enterprises (MSEs) represent appropriate opportunities for women entrepreneurs, as they respond flexibly to entry, change and innovation. These potentials have not yet been realized in an optimal fashion because large numbers of women work in the informal sector while their contribution to value-added is not included in national accounts. This study have identified variety of constraints on women and their inability to up grade their production continuously, which include poor access to market information technology, poor linkages with support services and an unfavorable policy and regulatory environment. These constraints are exacerbated by the need to compete in an aggressive business environment with rapid technological changes and the globalization of production, trade and financial flows.

Furthermore, in some African societies, women entrepreneurs face additional obstacles. This is due to deeply rooted discriminatory socio-cultural values and traditions embedded particularly in the policy and legal environment and in institutional support mechanisms. In many instances, women are unable to benefit from available services. This study is of the opinion that there is a need to overcome the constraints in order to tap the productive potential of women and to enhance their contribution to industrial development. Partnerships should be encouraged with the governments to promote the establishment of an enabling environment for women entrepreneurs with support institutions to provide women with the services they require.

This paper is of the opinion that the major factors to enhancing women entrepreneurship is provision of access to economic opportunities, credit, know-how through trainings, and improved technologies. This will upgrade their technical capabilities and their entrepreneurial and business skills. To realize the above there should be reduction of inequalities between men and women arising from institutionalized practices as reflected in legal, business and financial systems. The goal could be reached through capacity building, re-orienting existing institutions and a 
commitment to improving women's access to productive resources; needless to say, these should be accompanied by an improvement in the policy and legal framework to achieve the highest impact.

\section{Problems encountered by African women entrepreneurs}

Entrepreneurship is not an individual process but a collective effort, involving many actors in addition to the entrepreneur herself. To be able to succeed, the entrepreneur requires access to information, technology and market. Women entrepreneurs are often prevented from running competitive businesses because of their relatively low education levels and slow establishment of business linkages (Gemini, 1993; Gibb, 1998). These generally limit their access to various support services. If they are given the right support, they could be part of the collective process of enterprise development.

The multiple roles of women in the family put a brake on their risk taking. In many African countries, women spend most of their income on the household, particularly on food and education for their children. Many of them are afraid to invest their limited funds into a business for fear of failure. In general, women tend to copy each other rather than to produce something new for their market or to look for a new market for their products.

In addition to the socio-cultural impediments, most African women face many other problems. The most outstanding ones are:

- Limited access to necessary technologies due to lack of information and know-how.

- Difficulty in finding appropriate production sites at competitive prices.

- Inadequate skills in the fields of production, business management and marketing.

- Lack of skills for product diversification.

- Inadequate infrastructure and utilities.

- Limited access to finance.

The lack of awareness on the part of women entrepreneurs of new developments within the policy and legal framework of their countries acts as a significant constraint (World Bank, 2005). In Zimbabwe, the main problem articulated by women entrepreneurs 
in starting and operating a business is gender related discrimination. The expected role and capacity of women in Zimbabwean society create difficulties and problems at many levels. Traditionally, a married woman in Zimbabwe is not expected to head a household because the husband plays this role (Gemini, 1993; Skapa, 2005). She is normally not expected to make economic decisions such as starting and running a business of her own. Even those women who succeeded in setting up and managing their businesses find it very difficult to overcome cultural barriers which seem to be deeply ingrained in the society. Hence, Zimbabwean women face stiff competition in expanding a formal sector. This situation affects women's exposure to businesses and new ideas. Cutura (2006) reported similar voices of women entrepreneurs in Kenya.

In Senegal, the distribution of roles within the family and the supremacy of the male head of household place women at an inferior level (Gelb, 2001). Senegalese women do not enjoy equal status in certain areas, particularly in property and inheritance. This is not due to the legal context but to socio-cultural values and ignorance. Similarly in Morocco, due to the discriminatory practices prescribed by the traditional legal system regarding the role and place of women in the family and society, allowed the "moudouwana," the position of married women constitutes an important obstacle to their undertaking any entrepreneurial activities (Baumol,1990; UNDP,1995). The economic activities of married women are usually limited to household since her contact with the outside world remains limited. Whereas in some areas, women are not allowed to work the land due to a superstition that the land will not yield crops if women touch the plough, in others, they play major roles in food production.

All the above suggest that African populations are composed of different ethnic groups with varied attitudes and traditional beliefs towards women. Due to these and other discriminatory practices, women find it extremely difficult to break away from traditions and behave independently (ILO, 1993; UNIDO, 2004).

In Mali, many aspiring women entrepreneurs reiterated that the lack of financial means is a major problem in the startup phase, that there are not many credit lines at the banks targeting small 
entrepreneurs (UNDP, 1995; UNIDO, 2004), while Women entrepreneurs in Nigeria remain on the periphery of the national economy. The concentration of activities of women in business is located in the areas of crafts, hawking, personal services and the retail sector. There are low participation levels of women entrepreneurs in value-adding business opportunities.

Some of the barriers to promoting women in business include cultural and societal problems, the psychological impact of cultural norms, employment legislation and policy, lack of information, training, finance, markets, technology and business infrastructure, fragmented approaches to identifying issues and developing strategy to influence policy affecting business and government intervention. This constitutes major impediment to women and minorities enterprise development (ILO, 1993; World Bank, 2005).

Accordingly, more and more women are taking the role to informal sector entrepreneurship. Women entrepreneurs represent untapped reservoir for job creation, economic growth and social development. Despite the growth of these businesses, many women owned businesses remain stunted by lack of appropriate managerial skills, access to business resources, networking opportunities and access to new markets.

In general, many African women lack the education needed to spur successful entrepreneurship. Most of them are ignorant of new technologies or unskilled in their use and often unable to do research and gain the necessary training (UNIDO, 2004: 2005). Although great advances are made in technology, many women's illiteracy, structural difficulties and lack of access to technical training prevent them access to the benefit of the new technology. This lack of knowledge and the continuing treatment of women as second class citizens keep them in a pervasive cycle of poverty. In short, uneducated and untrained women in most African countries face significant challenges and barriers in providing for themselves and their families an independent enterprise as means of support.

The nature of the many challenges and obstacles facing African women entrepreneurs suggest that their full economic potential is not actualized and that African woman do not feature on the mainstream of the economic agenda. 


\section{Conclusion}

This paper concludes that there is the need to promote, support and strengthen African women entrepreneurship development. There is the need to provide direct training support to women enterprises and strengthen institutional capacity in developing policies and programs for the integration of African women. The paper also concludes that women's entrepreneurial activities are not only a means for economic survival but also have positive social repercussions for the women themselves and their social environment. Women's productive activities empower them economically and enable them to contribute more to overall development.

The paper identifies variety of constraints on women and the ability of women to up grade their production continuously. These constraints are exacerbated by the need to compete in an aggressive business environment with rapid technological changes and the globalization of production, trade and financial flows. The paper also emphasizes that the key to enhancing women entrepreneurship access to economic opportunities is to provide them with access to know-how, technologies, credit and training to upgrade their technical capabilities and their entrepreneurial and business skills, whether in artisan production or in high-tech industries. In doing so, the aim should be to reduce the inequalities between men and women arising from institutionalized practices as reflected in legal, business and financial systems. This goal can be reached through capacity building, re-orienting existing institutions and a commitment to improving women's access to productive resources and to managerial and technical training. Needless to say, these should be accompanied by an improvement in the policy and legal framework to achieve the highest impact.

\section{Recommendations}

- It is recognized that full and equal contribution of men and women in all sector are indispensable to achieve the objectives of sustainable economic and industrial program for women development in African countries. In this connection, it is important to design more entrepreneurship programs such as women's business centre program, small business administration (SBA) program with an extensive network of field offices and 
partnerships with the public and private organizations. These are not only important to help start, build and grow business but for women and minorities to keep up with changes in the global environment. The importance of entrepreneurship program is also to act as a collective advocate for women and minorities in business in the local community or at regional and national level. Such advocacy efforts will make lending institutions make financial contributions by offering loans at minimal rates to local credit unions.

- African women and minorities should be given the support and training needed for them to move away from a mere survival level of production and income generation and to achieve growth and competitiveness.

- African women and minorities entrepreneurs should be encouraged and taught to develop new entrepreneurial lifestyles and capacities, develop global sensitivity, and possess flexible orientation and strategic thinking. These are issues which should be addressed by individual government.

- In addition, there is the need for programs to focus on the institutional capacity building, which would provide practical hands-on-skills upgrading programs for women in both business management and production techniques. For this purpose, women's associations, local training institution and NGOs should be given the necessary assistance by concerned bodies such as national governments, international donors (UN, UNDP, World Bank) and international labor organizations (ILO). Accordingly, networking of women with national, regional and international business associations should be facilitated by the government and international organizations.

- Women's desks or bureaus should play an active role in facilitating the access of women and minorities entrepreneurs to various services and networking possibilities, while technical cooperation projects and programs should play a facilitating role in networking.

- Centre for entrepreneurship and subject of entrepreneurship as part of high school curriculum in all public schools should be established through each country's ministry of education in 
partnership with Commission of High Education and International Labor Organization (ILO). A pilot test of this kind is currently being conducted in Philippines. 


\section{References}

Baumol, W. J. 1990. Entrepreneurship, productive, unproductive and destructive. Journal of Political Economy, vol. 98: 89-92.

Brock, W.A. and Evans, D.S. 1989. Small Business Economics. Small Business Economics, vol. 1: 7-20.

Carrce, M.A. 1997. Market dynamics, evolution and smallness. Amsterdam: Thesis Publishers and Tinbergan Institute.

Casson, M.1995. Entrepreneurship and Business Culture. Studies in the Economics of Trust. Aldershot (UK): Edward Elgar.

Casson, M.2003. The Entrepreneur: An economic Theory. $2^{\text {nd }}$ ed. Cheltenham (UK): Edward Elgar.

Cutura, J. 2006. Report on Voices of Women Entrepreneurs in Kenya. Washington D.C: International Finance Corporation.

Galambos, L. 1970. The Emerging Organizational Synthesis in Modern American History. Business History Review: 279-290.

Gelb, A. 2001. Gender and Growth, Africa's Missed Potential. Africa regional findings, No. 197, December. Washington D.C, World Bank.

Gemini, C. April 1993. Business linkages and enterprise development in Zimbabwe, Technical Report № 53 .

Giannetti, M and Simonov,A. 2003. Social interactions and entrepreneurial activity. Dept of Finance, Stockholm School of Economics, Stockholm, Sweden. 
Gibb, A. June, 1998. Entrepreneurial core capacities, competitiveness and management development in the $21^{\text {st }}$ century. University of Durham.

Hagen, E. 1962. On the Theory of Social Change: How economic Growth Begins. Homewood: Dorsey Press.

Hisrick, R.D, Ozturk S.A 1999. Women entrepreneurs in a developing economy. The Journal of Management Development, Vol. 18, No 2:144124.

International Labor Organization (ILO) 1993. The urban informal sector in Ethiopia: Towards Micro and Small Enterprise Development, Geneva.

Jenks, L. H. 1944. Railroads as an Economic Force in American Development, The Journal of Economic History, 4: 18-20.

Jenks, L. H. 1949. Role Structure of Entrepreneurial Personality. In Change and the Entrepreneur: Postulates and the Patterns for Entrepreneurial History, Harvard University Research Center in Entrepreneurial History. Cambridge: Harvard University Press.

Kilby, P.1971. Entrepreneurship and Economic Development. New York: Free Press.

Landes, D. 1958. Bankers and Pashas: International Finance and Economic Imperialism in Egypt. London: Heinemann.

Leff, N. H. 1979. Entrepreneurship and Economic Development: The Problem Revisited, Journal of Economic Literature 17: 46-64.

Low, M, Ian C. M. 1988. Entrepreneurship: Past Research and Future Challenges. Journal of Management 14: 139-161. 
Morris, D. 1967.Values as an Obstacle to Economic Growth in South Asia: An Historic Survey. Journal of Economic History 27: 588-607.

OECD 1997. Entrepreneurship and SMEs in transition economy. The Visegrad Conference, OECD Proceedings, Paris.

OECD 1998. Fostering Entrepreneurship, the OECD Jobs Strategy, Paris.

Oviatt, B, Patricia M. 1994. Toward a Theory of International New Ventures. Journal of International Business Studies 25: 45-64

Petrin, T. 1994. Entrepreneurship as an economic force in rural development. Paper presented at the seventh FAO/REU International Rural Development Summer School, Herrsching, Germany.

Sass, S. 1978. Entrepreneurial Historians and History: An essay in Organized Intellect.” PhD diss., Johns Hopkins University.

Say, J.B. 1855. A Treatise on Political Economy, trans. Clement Biddle. Philadephia: Lippincott, Grambo \& Co.

Schumpeter, J. 1947. The Creative Response in Economic History. The Journal of Economic History 7: 149-159.

Schumpeter, J. 1975. Capitalism, Socialism and Democracy. New York. Harper.

Skapa, B.C. 2005. The small scale and informal enterprise sector in Zimbabwe, A policy frame work, Five Years Development Plan, Harare.

Starcher, D.C. 2003. Women entrepreneurs: Catalysts for transformation. Available at http:// www.ebbf.org/women.htm.

Stevenson, H.H 1985. New business ventures and the entrepreneurs. Homewood, IL. Irwin. 
Stotsky, J.G. 2006. Gender and its relevance to macroeconomic policy: A survey. IMF Working Paper No WP/06/233. Washington D.C, International Monetary Fund.

Tyson, L.T, Petrin, T.1994. Promoting entrepreneurship in central and Eastern Europe, Small Business Economics, vol.6: $1-20$.

United Nations Development Program (UNDP). 1995. Progress of the world's women, work and poverty. New York: United Nations.

UNDP 2005. Human Development Report, New York.

United Nation Industrial Development Organization (UNIDO) 2004.

Women, industry and entrepreneurship; Women in Industry Series, Vienna, Austria.

UNIDO. 2005. Training program for women entrepreneur in the processing industry, Report on the Needs Assessment Mission to Ethiopia, Vienna.

Wallterstein, Immanuel. 1974. The Modern world System:

Capitalist Agriculture and the Origins of the European World Economy in the Sixteenth Century. New York: Academic Press.

Weiner, M. 1966. Modernization: The Dynamics of Growth. New York: Basic Books.

Wilken, P.H. 1979. Entrepreneurship: A Comparative and Historical Study. Norwood NJ: Ablex Publishing Corporation.

World Bank. 2005. Enhancing women's participation in economic development. Washington D.C.

Yamamura, K. 1968. A Re-examination of Entrepreneurship in Meiji Japan. Economic History Review 21: 144-158. 